\title{
Clinical relevance between sodium-glucose co-transporter 2 inhibitors and lipid profiles in Asian patients with type 2 diabetes mellitus: a systematic review with a meta- analysis of randomized controlled trials
}

\author{
Junichi Mukai, Ayano Yoshiyama and Rie Kubota
}

\begin{abstract}
Background: Few systematic reviews have examined the effects of sodium-glucose co-transporter 2 inhibitors (SGLT2is) on lipid profiles in Asian patients with type 2 diabetes mellitus. We conducted a systematic review with a meta-analysis to summarize the available literature and confirm the effects of SGLT2is on lipid profiles in these patients.

Methods: We searched the electronic databases MEDLINE, CENTRAL, and Ichushi-web for studies from the dates of their earliest publication to July 2018, and there was no language restriction. Trials were included if they were randomized controlled trials (RCTs) (1) comparing the effects of SGLT2is with a placebo in Asian patients with type 2 diabetes mellitus (18years or older), and (2) reporting HbA1c and at least one lipid parameter, such as triglycerides (TG), high-density lipoprotein cholesterol (HDL-C), or low-density lipoprotein cholesterol (LDL-C). The weighted mean difference with a 95\% confidence interval (Cl) was calculated using a random-effects model.

Results: Among the 630 studies retrieved, 17 RCTs that included 4485 patients were ultimately included in our review. Fourteen RCTs were conducted in Japan. The durations of RCTs ranged between 12 and 24 weeks. SGLT2is significantly improved $\mathrm{HbA} 1 \mathrm{C}$ [mean difference $-0.80(95 \% \mathrm{Cl}-0.96$ to -0.64$) \%, p<0.00001$ ], TG [mean difference $-16.42(95 \% \mathrm{Cl}-22.71$ to -10.12$) \mathrm{mg} / \mathrm{dL}, p<0.00001$ ], and HDL-C [mean difference 3.36 (95\%Cl 2.73 to 3.98$) \mathrm{mg} / \mathrm{dL}, p<0.00001$ ], but significantly deteriorated LDL-C [mean difference $3.00(95 \% \mathrm{Cl} 1.18$ to 4.82$) \mathrm{mg} / \mathrm{dL}, p<0.001$ ]. The LDL-C/HDL-C ratio was not significantly different between SGLT2is and a placebo [mean difference -0.01 ( $95 \% \mathrm{Cl}-0.08$ to 0.06$), p<0.74$ ].

(Continued on next page)
\end{abstract}

\footnotetext{
* Correspondence: mukai11@kitasato-u.ac.jp

Division of Clinical Pharmacy (Laboratory of Clinical Pharmacy Education) and Research and Education Center for Clinical Pharmacy, School of Pharmacy, Kitasato University, 5-9-1 Shirokane, Minato-ku, Tokyo 108-8641, Japan
}

C C The Author(s). 2020 Open Access This article is licensed under a Creative Commons Attribution 4.0 International License, which permits use, sharing, adaptation, distribution and reproduction in any medium or format, as long as you give appropriate credit to the original author(s) and the source, provide a link to the Creative Commons licence, and indicate if changes were made. The images or other third party material in this article are included in the article's Creative Commons licence, unless indicated otherwise in a credit line to the material. If material is not included in the article's Creative Commons licence and your intended use is not permitted by statutory regulation or exceeds the permitted use, you will need to obtain permission directly from the copyright holder. To view a copy of this licence, visit http://creativecommons.org/licenses/by/4.0/ The Creative Commons Public Domain Dedication waiver (http://creativecommons.org/publicdomain/zero/1.0/) applies to the data made available in this article, unless otherwise stated in a credit line to the data. 
(Continued from previous page)

Conclusion: The present results suggest that in Asian patients with type 2 diabetes mellitus, TG and HDL-C values were better, while LDL-C values were worse with SGLT2is than with a placebo. However, the negative impact of SGLT2is on lipid profiles was modest. Further RCTs with a longer duration or conducted in other Asian countries are needed to provide further evidence to support the clinical relevance of changes in lipid profiles. The present results will be informative for SGLT2is users with concerns regarding the effects of SGLT2is on lipid profiles.

Keywords: Meta-analysis, Systematic review, Sodium-glucose co-transporter 2 inhibitors, Lipid profiles, Asian descent, Type 2 diabetes mellitus

\section{Background}

Sodium-glucose co-transporter 2 inhibitors (SGLT2is) are a new class of oral hypoglycemic agents that exert effects on glycemic control and weight loss [1]. The EMPA-REG OUTCOME study [2], which included patients with type 2 diabetes mellitus at a high risk of cardiovascular events, recently demonstrated that empagliflozin lowered the risk of death from cardiovascular events. The CANVAS program also showed that patients treated with canagliflozin had a lower risk of cardiovascular events [3]. As elevated levels of low-density lipoprotein cholesterol (LDL-C) are a well-established risk factor for cardiovascular disease $[4,5]$, and SGLT2is may reduce these levels. However, there are two conflicting studies on the effects of SGLT2is. The American Diabetes Association guidelines reported that SGLT2is had a negative impact on LDL-C [6], while an RCT conducted in Japan showed the opposite effects [7]. Racial differences generally exist between Asians and non-Asians. For example, Asians are more likely to have a lower body mass index than those of European descent [8]. They also have a higher percent body fat than Caucasians with the same body mass index [9]. Regarding lipid profiles, a recent study by Zhang and colleagues [10] indicated that the effects of metformin on high-density lipoprotein cholesterol (HDL-C) varied between ethnic groups. Based on these findings, we hypothesized that the effects of SGLT2is on lipid profiles differed between Asian patients and those of European descent.

To the best of our knowledge, few systematic reviews have examined the effects of SGLT2is on lipid profiles in Asian patients with type 2 diabetes mellitus. A systematic review by Cai and colleagues [11] investigated the effects of SGLT2is in these patients; however, the findings obtained need to be interpreted with caution because the term "Asian patients" used in their metaanalysis indicates that there are $50 \%$ or more Asian patients in each RCT selected. We herein conducted a systematic review with a meta-analysis to summarize the available literature and evaluate the clinical relevance between SGLT2is and lipid profiles in Asian patients with type 2 diabetes mellitus.

\section{Methods}

\section{Searching strategies to identify randomized controlled} trials (RCTs)

We searched the electronic databases MEDLINE, The Cochrane Central Register of Controlled Trials (CENTRAL), and Japana Centra Revuo Medicina (Ichushi-web) for studies from the dates of their earliest publication to July 2018. We included nine types of SGLT2is: canagliflozin (CANA), dapagliflozin (DAPA), empagliflozin (EMPA), ertugliflozin, ipragliflozin (IPRA), luseogliflozin (LUSEO), remogliflozin, sergliflozin, and tofogliflozin (TOFO). We used individual SGLT2i names, alternative names, "sodium-glucose transporter 2", and "SGLT2 inhibitors" as search terms. We restricted our search to "randomized controlled trial" in these electronic databases. A reference search was also implemented from relevant studies in order to identify more RCTs. We did not impose any language restriction. Trials were included if they were RCTs (1) comparing the effects of SGLT2is with a placebo in Asian patients with type 2 diabetes mellitus (18 years or older), and (2) reporting HbAlc and at least one lipid parameter, such as triglycerides (TG), HDL-C, or LDL-C. We excluded cross-over trials and RCTs involving healthy subjects. The study search was undertaken independently by two authors (AY and JM). Any discrepancies were settled by discussions between the two assessors. We extracted data on the trial country, trial design, comorbidities, co-interventions, daily dose of each SGLT2i, duration of the intervention, and lipid profiles: TG, HDL-C, and LDL-C, at baseline. Lipid profiles were set as the primary endpoint and the LDL-C/HDL-C ratio as the secondary endpoint. In order to convert mmol/L of TG, HDL-C, and LDL-C to $\mathrm{mg} / \mathrm{dL}$, we multiplied $\mathrm{mmol} / \mathrm{L}$ by $88.6,38.7$, and 38.7 respectively. Our systematic review with a metaanalysis did not require Ethics Committee approval.

\section{Quality assessment of each RCT}

Study quality was quantified by both the Jadad scale and risk of bias tool. The Jadad scale is used to evaluate the appropriateness of the randomization technique, the method used for double-masking, and descriptions of dropouts or withdrawals [12]. The scale ranges between zero and five. We included studies that scored 4 points 


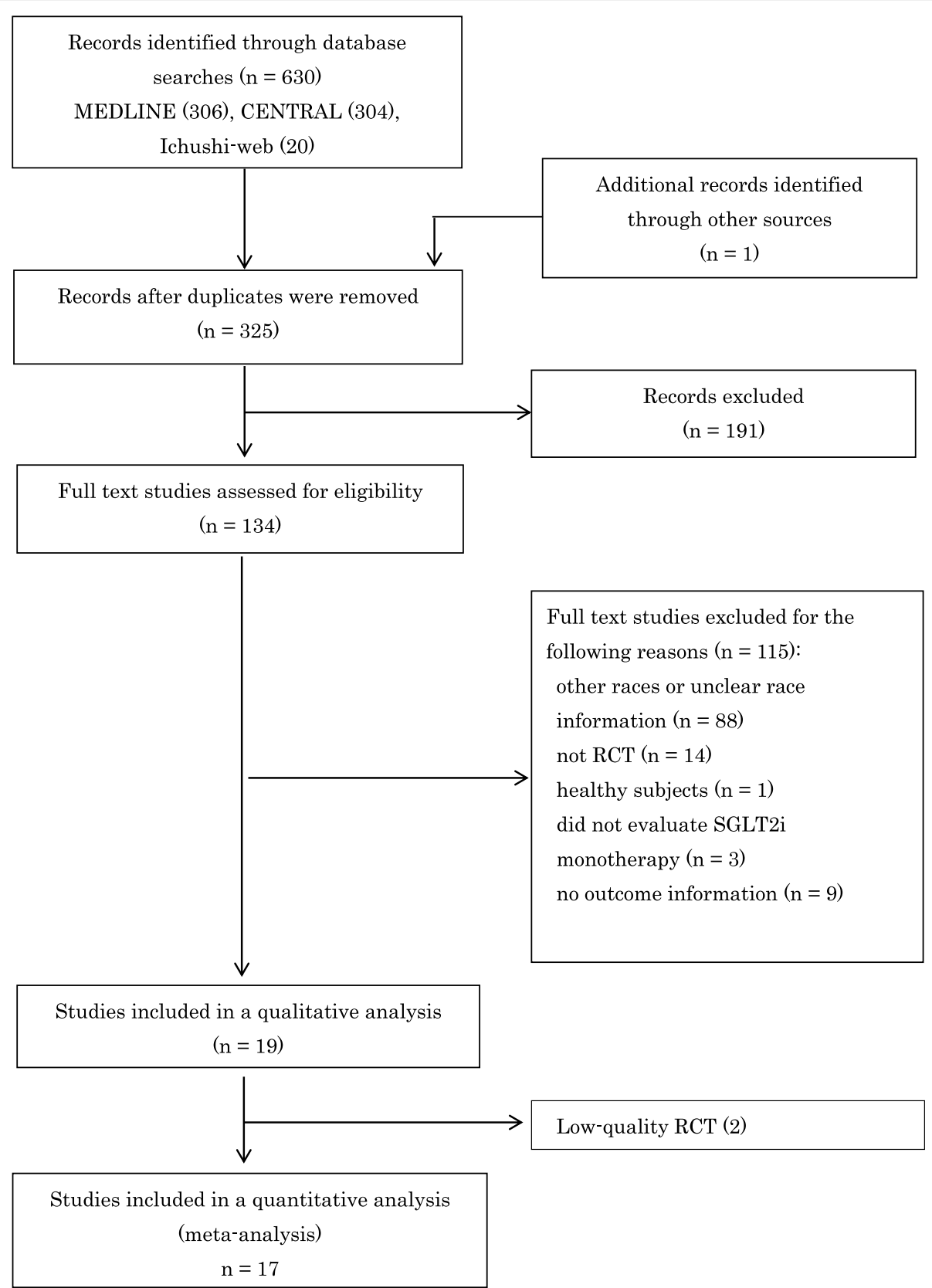

Fig. 1 Identification process for eligible RCTs following PRISMA. Abbreviations: SGLT2i, sodium-glucose co-transporter 2 inhibitor; RCT, randomized controlled trial.

or higher in the analysis. The risk of bias for the studies was assessed based on the Cochrane Handbook [13]. Seven items were examined for the risk of bias: random sequence generation, allocation concealment, the blinding of participants and personnel, blinding of outcome assessments, incomplete outcome data, free of selective reporting, and a baseline imbalance for lipid parameters as other sources of bias. Each of the seven items was scored as a "low risk", "unclear risk", or "high risk".

\section{Statistical analysis}

We calculated the weighted mean difference with a $95 \%$ confidence interval (CI) for each outcome. The heterogeneity of each outcome was evaluated using chisquared and $\mathrm{I}^{2}$ statistics. A value of $50 \%$ or more was defined to represent marked heterogeneity based on the Cochrane handbook [13]. We used a random-effects model (the DerSimonian and Laird method [14]) to assess outcomes more conservatively. In the meta-analysis, multiple SGLT2i groups in a single trial were combined 
Table 1 Characteristics of 17 randomized, double-blind, controlled trials included in the meta-analysis

\begin{tabular}{|c|c|c|c|c|c|c|c|c|c|}
\hline Author & Country & $\begin{array}{l}\text { Comorbid, } \\
\text { co-intervention }\end{array}$ & $\begin{array}{l}\text { Doses [mg/day], } \\
\text { (n) }\end{array}$ & $\begin{array}{l}\text { Duration } \\
\text { (weeks) }\end{array}$ & $\begin{array}{l}\mathrm{HbA1c} \\
\text { at } \\
\text { baseline } \\
(\%)\end{array}$ & $\begin{array}{l}\mathrm{TG} \\
\text { at baseline (mg/dL) }\end{array}$ & $\begin{array}{l}\mathrm{HDL}-\mathrm{C} \text { at } \\
\text { baseline (mg/ } \\
\mathrm{dL} \text { ) }\end{array}$ & $\begin{array}{l}\text { LDL-C at baseline } \\
(\mathrm{mg} / \mathrm{dL})\end{array}$ & $\begin{array}{l}\text { Jadad } \\
\text { Scale }\end{array}$ \\
\hline $\begin{array}{l}\mathrm{Ji} \\
2014[16]\end{array}$ & $\begin{array}{l}\text { China, } \\
\text { Korea, } \\
\text { Taiwan } \\
\text { India }\end{array}$ & $\begin{array}{l}\text { Diet and } \\
\text { exercise }\end{array}$ & $\begin{array}{l}\text { DAPA: } 5 \text { (128), } 10 \\
\text { (133), } \\
\text { P: (132) }\end{array}$ & 24 & $\begin{array}{l}\text { DAPA: } \\
8.1,8.3 \\
\text { P: } 8.4\end{array}$ & NR & $\mathrm{NR}$ & NR & 5 \\
\hline $\begin{array}{l}\text { Kadowaki } \\
2014[17]\end{array}$ & Japan & $\begin{array}{l}\text { Diet and } \\
\text { exercise }\end{array}$ & $\begin{array}{l}\text { EMPA: } 5 \text { (110), } 10 \\
(109), \\
25 \text { (109), } 50 \text { (110), } \\
\text { P: (109) }\end{array}$ & 12 & $\begin{array}{l}\text { EMPA: } \\
7.9,7.9 \\
7.9,8.0 \\
\text { P: } 7.9\end{array}$ & $\begin{array}{l}\text { EMPA:148.8, 128.5, } \\
146.2,148.8, \text { P: } 144.4\end{array}$ & $\begin{array}{l}\text { EMPA: } 55.3 \\
58.8 \\
57.7,57.7, P: \\
57.3\end{array}$ & $\begin{array}{l}\text { EMPA: 127.3, 125.0, } \\
\text { 125.0, 123.8, P: } 124.2\end{array}$ & 4 \\
\hline $\begin{array}{l}\text { Kashiwagi } \\
\text { 2015A } \\
{[18]}\end{array}$ & Japan & $\begin{array}{l}\text { Renal } \\
\text { impairment, } \\
\text { diet/exercise, } \\
\text { or using an } \\
\text { OHA }\end{array}$ & $\begin{array}{l}\text { IPRA: } 50 \text { (118), } \\
\text { P: (46) }\end{array}$ & 24 & $\begin{array}{l}\text { IPRA: } 7.5 \text {, } \\
\text { P: } 7.5\end{array}$ & IPRA: 137.6, P: 123.4 & $\begin{array}{l}\text { IPRA: } 57.0, \mathrm{P}: \\
56.4\end{array}$ & $\begin{array}{l}\text { IPRA: } 114.3, \\
\text { P: } 112.4\end{array}$ & 5 \\
\hline $\begin{array}{l}\text { Lu } \\
2016 \text { [19] }\end{array}$ & $\begin{array}{l}\text { Korea, } \\
\text { Taiwan }\end{array}$ & $\begin{array}{l}\text { Diet, exercise, } \\
\text { and metformin }\end{array}$ & $\begin{array}{l}\text { IPRA: } 50 \text { (87), } \\
\text { P: (83) }\end{array}$ & 24 & $\begin{array}{l}\text { IPRA: } 7.7 \\
\text { P: } 7.8\end{array}$ & NR & $N R$ & NR & 5 \\
\hline $\begin{array}{l}\text { Kashiwagi } \\
\text { 2015B } \\
{[20]}\end{array}$ & Japan & $\begin{array}{l}\text { Diet and } \\
\text { metformin }\end{array}$ & IPRA: (112), P: (56) & 24 & $\begin{array}{l}\text { IPRA: } 8.3 \text {, } \\
\text { P: } 8.4\end{array}$ & IPRA: 165.4, P: 129.3 & $\begin{array}{l}\text { IPRA: 53.6, P: } \\
57.4\end{array}$ & $\begin{array}{l}\text { IPRA: 108.0, } \\
\text { P: } 113.6\end{array}$ & 4 \\
\hline $\begin{array}{l}\text { Kashiwagi } \\
\text { 2015C } \\
{[21]}\end{array}$ & Japan & Sulfonylurea & $\begin{array}{l}\text { IPRA: } 50 \text { (165), P } \\
\text { (75) }\end{array}$ & 24 & $\begin{array}{l}\text { IPRA: } 8.4 \\
\text { P: } 8.3\end{array}$ & IPRA: 159.6, P: 151.3 & $\begin{array}{l}\text { IPRA: } 57.6, \mathrm{P:} \\
58.4\end{array}$ & $\begin{array}{l}\text { IPRA: } 124.2, \\
\text { P: } 120.4\end{array}$ & 5 \\
\hline $\begin{array}{l}\text { Kashiwagi } \\
2015 D \\
{[22]}\end{array}$ & Japan & Pioglitazone & $\begin{array}{l}\text { IPRA: } 50 \text { (97), P: } \\
\text { (54) }\end{array}$ & 24 & $\begin{array}{l}\text { IPRA: } 8.2 \\
\text { P: } 8.4\end{array}$ & IPRA: 142.9, P: 135.2 & $\begin{array}{l}\text { IPRA: 61.1, P: } \\
61.3\end{array}$ & $\begin{array}{l}\text { IPRA: } 116.7 \\
\text { P: } 130.4\end{array}$ & 5 \\
\hline $\begin{array}{l}\text { Kashiwagi } \\
2015 \mathrm{E} \\
{[23]}\end{array}$ & Japan & $\begin{array}{l}\text { Diet and } \\
\text { exercise }\end{array}$ & $\begin{array}{l}\text { IPRA: } 50 \text { (62), P: } \\
(67)\end{array}$ & 16 & $\begin{array}{l}\text { IPRA: } 8.4 \\
\text { P: } 8.3\end{array}$ & IPRA: 159.4, P: 148.1 & $\begin{array}{l}\text { IPRA:56.0, P: } \\
52.1\end{array}$ & $\begin{array}{l}\text { IPRA: } 124.4 \\
\text { P: } 127.1\end{array}$ & 5 \\
\hline $\begin{array}{l}\text { Haneda } \\
2016[24]\end{array}$ & Japan & $\begin{array}{l}\text { Renal } \\
\text { impairment, } \\
\text { Diet/exercise } \\
\text { or using 1-2 } \\
\text { OHAs }\end{array}$ & $\begin{array}{l}\text { LUSEO: } 2.5-5.0 \\
\text { (95), P: (50) }\end{array}$ & 24 & $\begin{array}{l}\text { LUSEO: } \\
7.7, \text { P: } 7.7\end{array}$ & $\begin{array}{l}\text { LUSEO: 147.7, P: } \\
148.1\end{array}$ & $\begin{array}{l}\text { LUSEO:57.7, P: } \\
52.9\end{array}$ & $\begin{array}{l}\text { LUSEO: 115.1, } \\
\text { P: } 119.3\end{array}$ & 4 \\
\hline $\begin{array}{l}\text { Seino } \\
2014 A \\
{[25]}\end{array}$ & Japan & Diet & $\begin{array}{l}\text { LUSEO: } 2.5 \text { (79), P: } \\
\text { (79) }\end{array}$ & 24 & $\begin{array}{l}\text { LUSEO: } \\
\text { 8.1, P: } 8.2\end{array}$ & $\begin{array}{l}\text { LUSEO: } 149.5, \mathrm{P}: \\
141.5\end{array}$ & $\begin{array}{l}\text { LUSEO: } 58.0 \text {, } \\
\text { P: } 60.2\end{array}$ & $\begin{array}{l}\text { LUSEO: 131.0, } \\
\text { P: } 127.8\end{array}$ & 5 \\
\hline $\begin{array}{l}\text { Seino } \\
2014 B \\
{[26]}\end{array}$ & Japan & Diet & $\begin{array}{l}\text { LUSEO: } 1.0 \text { (55), } \\
2.5(56), \\
5(54), 10 \text { (58), P: } \\
(57)\end{array}$ & 12 & $\begin{array}{l}\text { LUSEO: } \\
7.8,8.1 \\
7.9,8.0 \\
\text { P: } 7.9\end{array}$ & $\begin{array}{l}\text { LUSEO: 156.1, 167.6, } \\
\text { 136.2, 124.7, P:165.7 }\end{array}$ & $\begin{array}{l}\text { LUSEO: } 56.7, \\
53.6, \\
54.2,58.7, \mathrm{P}: \\
55.0\end{array}$ & $\begin{array}{l}\text { LUSEO: 126.1, } \\
\text { 128.8, 115.4, 121.4, P: } \\
117.9\end{array}$ & 5 \\
\hline $\begin{array}{l}\text { Seino } \\
2014 C \\
{[27]}\end{array}$ & Japan & Diet & $\begin{array}{l}\text { LUSEO: } 0.5 \text { (60), } \\
2.5(61), \\
5 \text { (61), P: (54) }\end{array}$ & 12 & $\begin{array}{l}\text { LUSEO: } \\
8.2,8.1 \\
8.2, \text { P: } 7.9\end{array}$ & $\begin{array}{l}\text { LUSEO: 173.7, } \\
\text { 150.2, 160.4, P:170.0 }\end{array}$ & $N R$ & NR & 5 \\
\hline $\begin{array}{l}\text { Inagaki } \\
2016[28]\end{array}$ & Japan & $\begin{array}{l}\text { Diet, exercise, } \\
\text { and insulin }\end{array}$ & $\begin{array}{l}\text { CANA: } 100 \text { (76), P: } \\
\text { (70) }\end{array}$ & 16 & $\begin{array}{l}\text { CANA: } \\
\text { 8.9, P: } 8.9\end{array}$ & $\begin{array}{l}\text { CANA: 124.5, P: } \\
144.0\end{array}$ & $\begin{array}{l}\text { CANA: 61.9, } \\
\text { P: } 57.6\end{array}$ & $\begin{array}{l}\text { CANA: } 122.4, \\
\text { P: } 121.9\end{array}$ & 5 \\
\hline $\begin{array}{l}\mathrm{Ji} \\
2015 \text { [29] }\end{array}$ & $\begin{array}{l}\text { China, } \\
\text { Malaysia, } \\
\text { Vietnam }\end{array}$ & $\begin{array}{l}\text { Metformin alone } \\
\text { or metformin } \\
\text { plus } \\
\text { sulfonylurea }\end{array}$ & $\begin{array}{l}\text { CANA: } 100 \text { (223), } \\
300 \text { (227), P (226) }\end{array}$ & 18 & $\begin{array}{l}\text { CANA: } \\
\text { 8.0, } 8.0 \\
\text { P: } 7.9\end{array}$ & $\begin{array}{l}\text { CANA: } 163.7,180.8, \\
\text { P: } 169.1\end{array}$ & $\begin{array}{l}\text { CANA: } 51.0, \\
48.8, P: 49.1\end{array}$ & $\begin{array}{l}\text { CANA: } 104.3, \\
\text { 100.8, P: } 98.3\end{array}$ & 4 \\
\hline $\begin{array}{l}\text { Inagaki } \\
2014 \text { [30] }\end{array}$ & Japan & $\begin{array}{l}\text { Diet and } \\
\text { exercise }\end{array}$ & $\begin{array}{l}\text { CANA: } 100 \text { (90), } \\
200(88), \\
\text { P: (93) }\end{array}$ & 24 & $\begin{array}{l}\text { CANA: } \\
8.0,8.0 \\
\text { P: } 8.0\end{array}$ & $\begin{array}{l}\text { CANA: } 150.9,148.9, \\
\text { P: } 158.1\end{array}$ & $\begin{array}{l}\text { CANA: } 54.9, \\
55.3, \text { P: } 55.8\end{array}$ & $\begin{array}{l}\text { CANA: } 127.3 \\
\text { 120.1, P: } 124.8\end{array}$ & 5 \\
\hline $\begin{array}{l}\text { Inagaki } \\
2013 \text { [31] }\end{array}$ & Japan & $\begin{array}{l}\text { Diet and } \\
\text { exercise }\end{array}$ & $\begin{array}{l}\text { CANA: } 50(82), \\
100(74), \\
200(76), 300(75), \\
P:(75)\end{array}$ & 12 & $\begin{array}{l}\text { CANA: } \\
8.1,8.1 \\
8.1,8.2 \\
\text { P: } 8.0\end{array}$ & NR & $N R$ & $N R$ & 5 \\
\hline Kaku & Japan & Diet and & TOFO: 10 (57), 20 & 24 & TOFO: & NR & NR & NR & 5 \\
\hline
\end{tabular}


Table 1 Characteristics of 17 randomized, double-blind, controlled trials included in the meta-analysis (Continued)

\begin{tabular}{|c|c|c|c|c|c|c|c|c|c|}
\hline Author & Country & $\begin{array}{l}\text { Comorbid, } \\
\text { co-intervention }\end{array}$ & $\begin{array}{l}\text { Doses [mg/day], } \\
\text { (n) }\end{array}$ & $\begin{array}{l}\text { Duration } \\
\text { (weeks) }\end{array}$ & $\begin{array}{l}\mathrm{HbA1c} \\
\text { at } \\
\text { baseline } \\
(\%)\end{array}$ & $\begin{array}{l}\mathrm{TG} \\
\text { at baseline }(\mathrm{mg} / \mathrm{dL})\end{array}$ & $\begin{array}{l}\mathrm{HDL}-\mathrm{C} \text { at } \\
\text { baseline (mg/ } \\
\mathrm{dL})\end{array}$ & $\begin{array}{l}\text { LDL-C at baseline } \\
(\mathrm{mg} / \mathrm{dL})\end{array}$ & $\begin{array}{l}\text { Jadad } \\
\text { Scale }\end{array}$ \\
\hline 2014 [32] & & exercise & $\begin{array}{l}\text { (58), } \\
40 \text { (58), P: (56) }\end{array}$ & & $\begin{array}{l}8.5,8.3 \\
8.4 \\
P: 8.4\end{array}$ & & & & \\
\hline
\end{tabular}

CANA canagliflozin, DAPA dapagliflozin, EMPA empagliflozin, IPRA ipragliflozin, LUSEO luseogliflozin, TOFO tofogliflozin, OHA oral hypoglycemic agent, P placebo, $H D L-C$ high-density lipoprotein cholesterol, $L D L-C$ low-density lipoprotein cholesterol, $T G$ triglycerides, NR not reported

into a single group [13]. Subgroup analyses were performed by including only Japanese patients and only patients who were treated with SGLT2is as monotherapy. We used Egger's regression test [15] to assess publication bias more precisely when there were 10 RCTs or more in the meta-analysis [13]. All statistical analyses were performed with SPSS version 23.0 (SPSS Japan Inc., Tokyo, JAPAN) and review manager 5.3 software (Cochrane Collaboration, Oxford, UK). A $P$ value less than 0.05 was considered to be significant.

\section{Results}

We identified 630 studies in the database search. One hundred and thirty-four full texts were retrieved after screening titles and abstracts. Seventeen RCTs that include 4485 patients were ultimately included in our review. Figure 1 shows the identification process for eligible RCTs [16-32] following PRISMA [33]. Table 1 shows the characteristics of RCTs included in the meta-analysis. All trials were published in English. Six types of SGLT2is (CANA, DAPA, EMPA, IPRA, LUSEO, and TOFO) were collected.
Fourteen studies were conducted in Japan. The durations of RCTs ranged between 12 and 24 weeks.

\section{Quality assessment of each RCT}

The Jadad scale of the studies ranged between 4 and 5 points (Table 1 ). We also assessed the risk of bias of RCTs based on the Cochrane handbook [13]. Most studies were high-quality RCTs. "Low risk" was the highest in the domains of blinding of participants and personnel and blinding of outcome assessments. "Unclear risk" was the highest in the domain of baseline imbalance. "High risk" was not scored in all domains (Fig. 2). Egger's regression test showed no significant results in all primary results.

\section{Relationship between SGLT2is and changes in $\mathrm{HbA} 1$}

Fifteen trials were included in the meta-analysis. Statistical heterogeneity was observed among trials $\left(\mathrm{I}^{2}=89 \%\right)$. HbA1c values were significantly better with SGLT2is than with a placebo [mean difference $-0.80 \quad(95 \% \mathrm{CI}-0.96$ to -0.64$) \%, \quad p<$ 0.00001], and all types of SGLT2is showed a significant result in the sub-group analysis. The IPRA

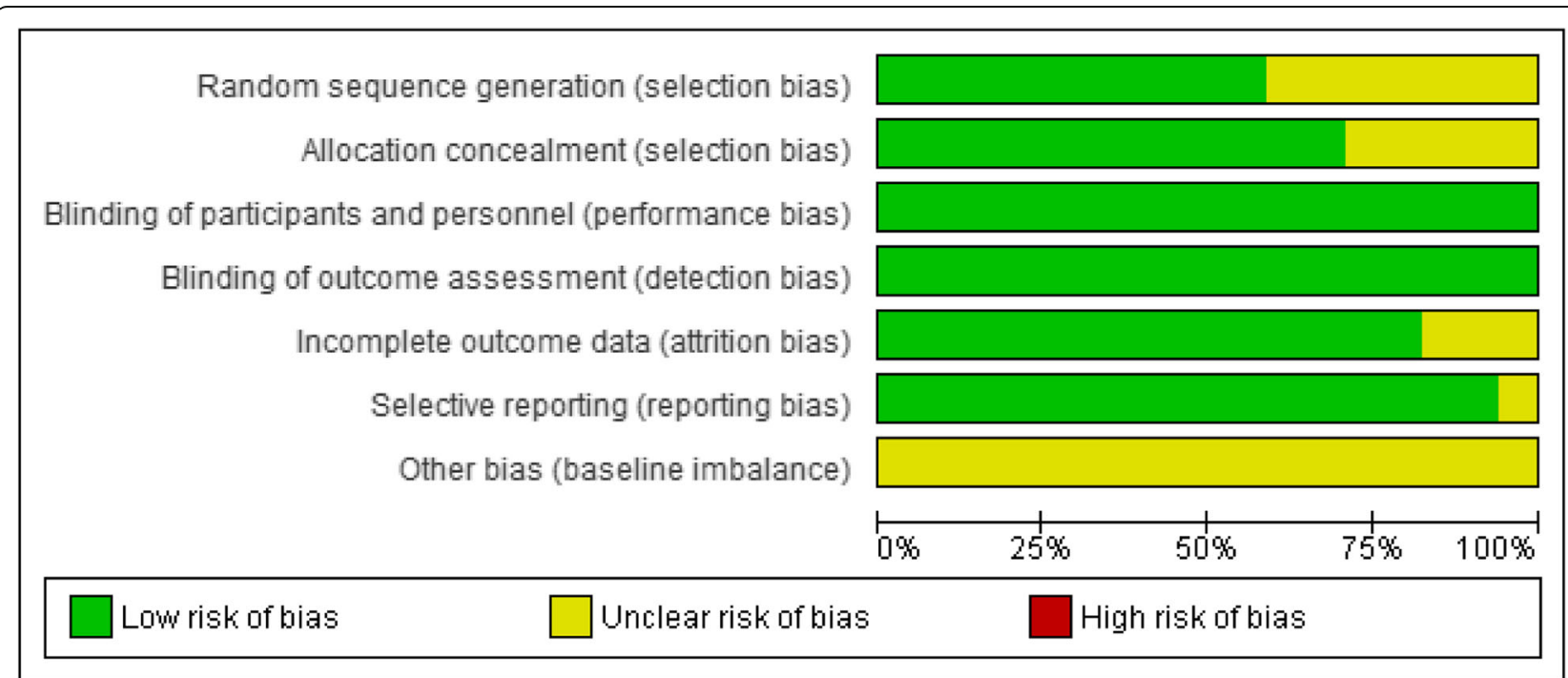

Fig. 2 Risk of bias graph of 17 randomized controlled trials 


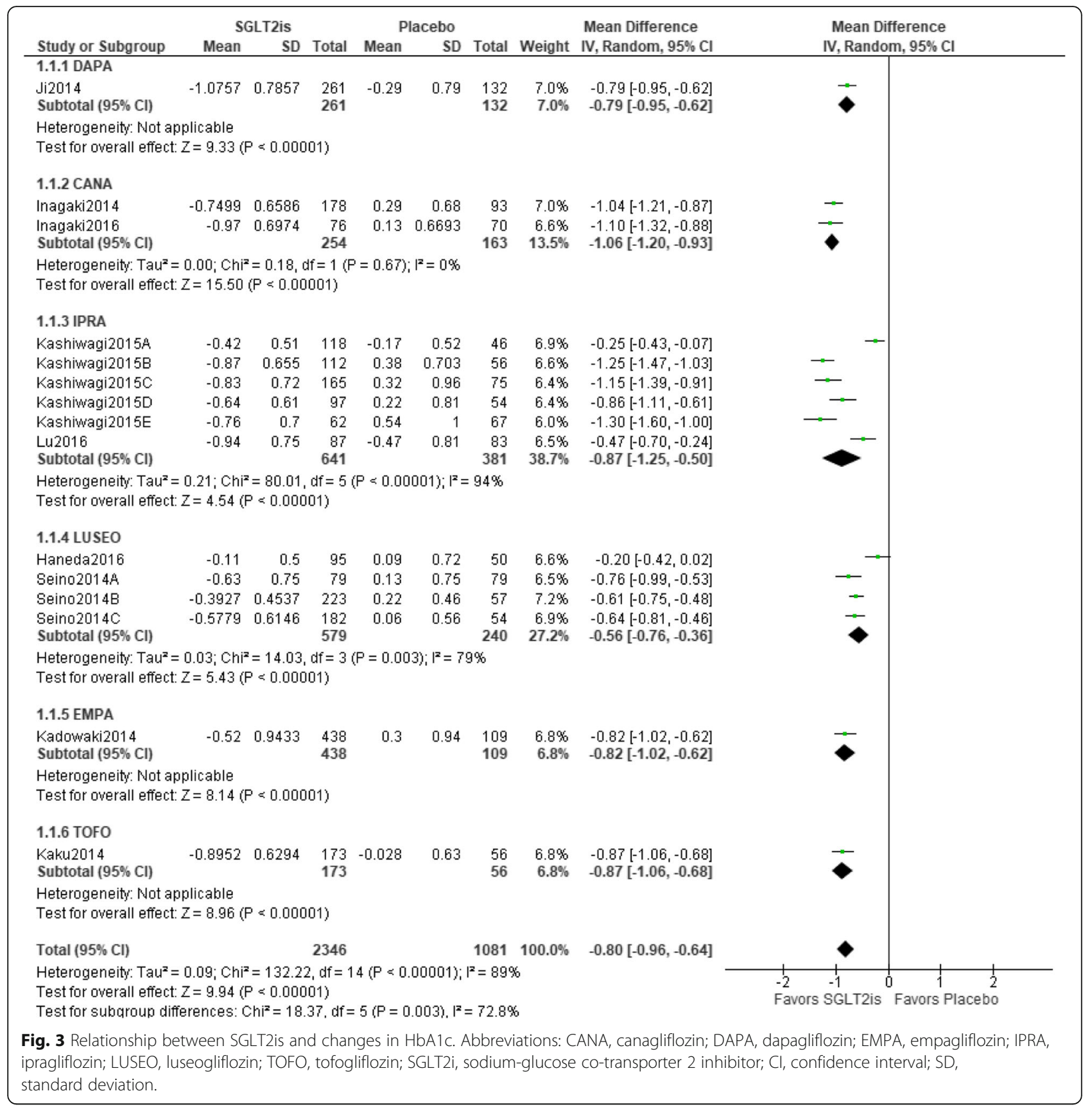

group had the highest weight $(38.7 \%)$, whereas the EMPA and TOFO groups had the lowest weight (6.8\% each) (Fig. 3).

\section{Relationship between SGLT2is and changes in TG}

Fifteen trials were included in the meta-analysis. Statistical homogeneity was observed among trials $\left(\mathrm{I}^{2}=4 \%\right)$. TG values were significantly better with SGLT2is than with a placebo [mean difference 16.42 (95\%CI -22.71 to -10.12$) \mathrm{mg} / \mathrm{dL}, \quad p<$ $0.00001]$, and the three types of SGLT2is examined
(IPRA, LUSEO, and EMPA) showed a significant result in the sub-group analysis. The IPRA group had the greatest weight $(37.6 \%)$, whereas the TOFO group had the lowest weight (1.3\%) (Fig. 4).

\section{Relationship between SGLT2 is and changes in HDL-C}

Fourteen trials were included in the meta-analysis. Statistical homogeneity was observed among trials $\left(\mathrm{I}^{2}=0 \%\right)$. HDL-C values were significantly better with SGLT2is than with a placebo [mean difference 3.36 (95\%CI 2.73 to 3.98$) \mathrm{mg} / \mathrm{dL}, p<0.00001]$, and 


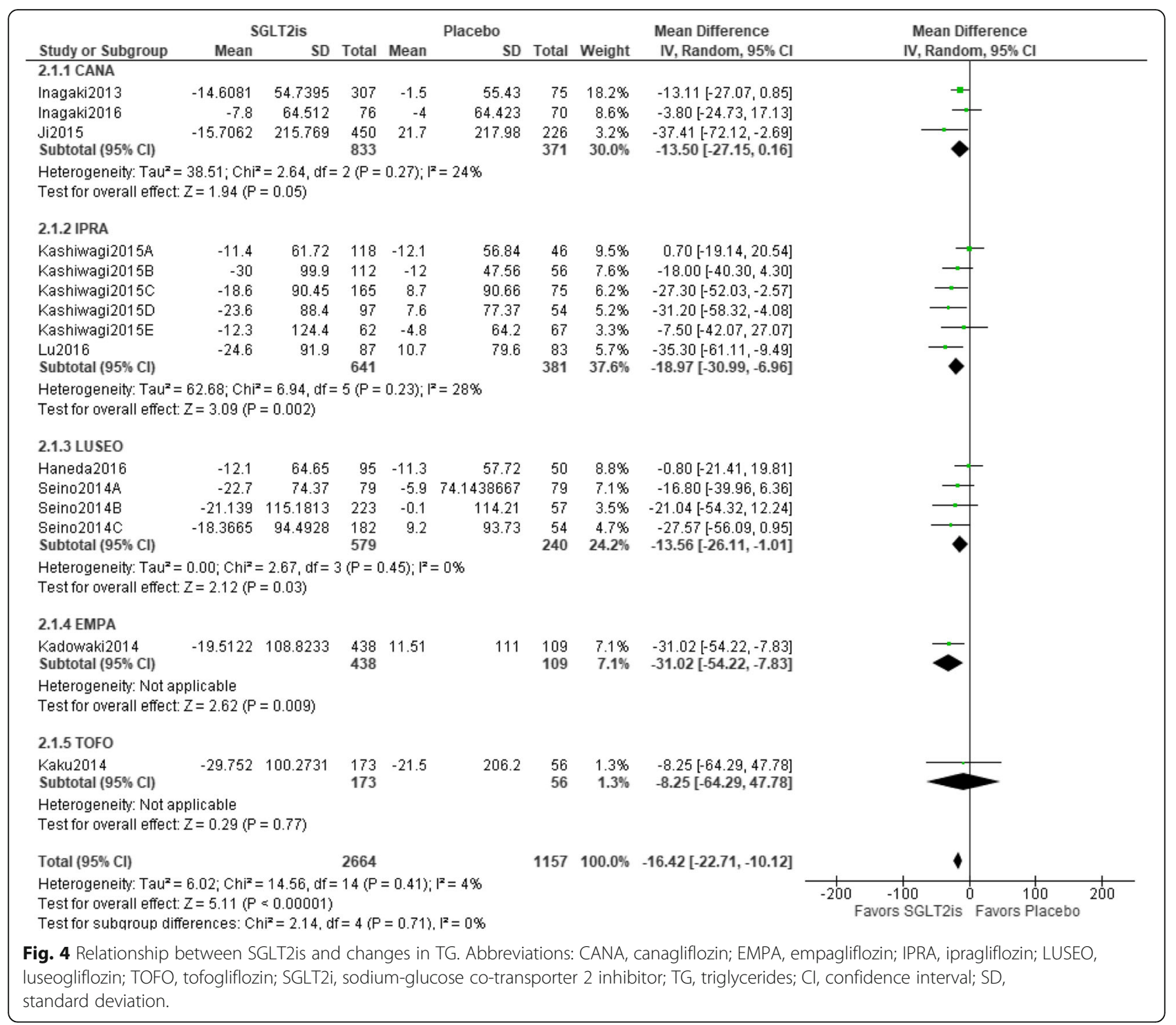

all types of SGLT2is showed a significant result in the sub-group analysis. IPRA group had the greatest weight $(40.0 \%)$, whereas EMPA group had the lowest weight (6.0\%) (Fig. 5).

\section{Relationship between SGLT2is and changes in LDL-C}

Fourteen trials were included in the meta-analysis. Statistical homogeneity was observed among trials $\left(\mathrm{I}^{2}=6 \%\right)$. LDL-C values were worse with SGLT2is than with a placebo [mean difference 3.00 (95\%CI 1.18 to 4.82$) \mathrm{mg} / \mathrm{dL}, p<0.001$ ], and only the CANA group showed a significant result in the sub-group analysis. The IPRA group had the greatest weight (38.1\%), whereas the TOFO group had the lowest weight (7.2\%) (Fig. 6).

\section{Relationship between SGLT2is and changes in the LDL-C/ HDL-C ratio}

Three trials were included in the meta-analysis. Statistical homogeneity was observed among trials $\left(\mathrm{I}^{2}=1 \%\right)$. The LDL-C/HDL-C ratio was not significantly different between SGLT2is and a placebo [mean difference $-0.01(95 \% \mathrm{CI}-0.08$ to 0.06$), p<0.74]$, and none of the groups showed a significant result in the subgroup analysis. The CANA group had the greatest weight (81.5\%) (Fig. 7).

\section{Additional analyses}

The results of the sub-group analysis including only Japanese patients and only patients who were treated with SGLT2is as monotherapy were consistent with the main results (Table 2). 


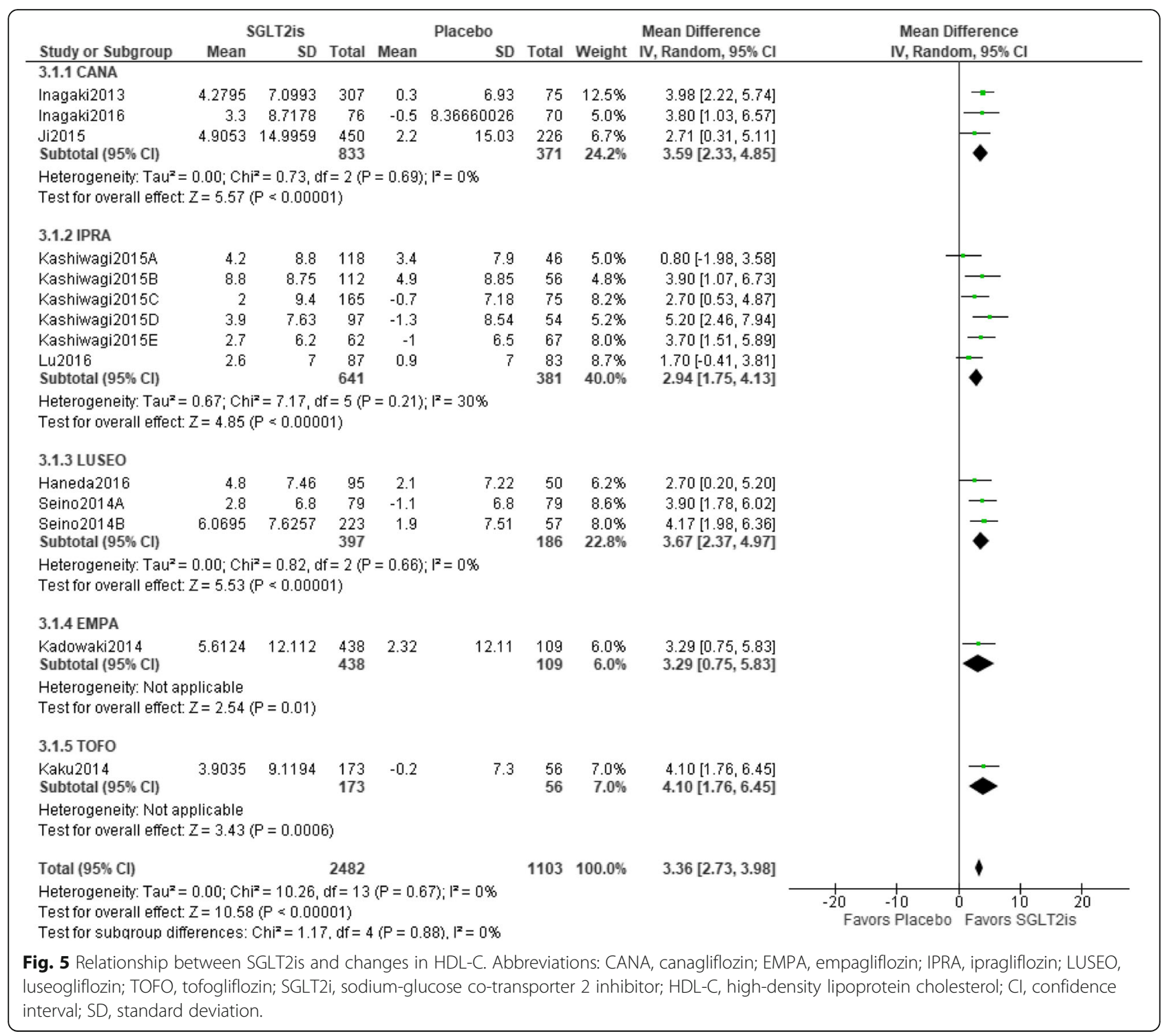

\section{Discussion}

We herein conducted a systematic review with a meta-analysis to summarize the available literature and confirm the effects of SGLT2is on lipid profiles in Asian patients with type 2 diabetes mellitus. The present study, which consisted of 17 RCTs including 4485 Asian patients with type 2 diabetes mellitus, suggests that TG and HDL-C values were better, whereas LDL-C values were worse with SGLT2is than with a placebo and also showed that there was no heterogeneity $\left(\mathrm{I}^{2} \leq 6 \%\right)$ in each lipid profile.

Our results for lipid outcomes were consistent with the meta-analysis by Cai and colleagues [11]; a significant, but small change was observed in lipid outcomes, and these outcomes indicated high heterogeneity $\left(\mathrm{I}^{2}>90 \%\right)$. This heterogeneity was attributed to their meta-analysis including RCTs with different inclusion criteria [11]. Total heterogeneity $\left(\mathrm{I}^{2} \leq 6 \%\right)$ may also have been attributed to most of the SGLT2i subgroups having low heterogeneity in our analysis. Total heterogeneity was higher when we excluded the subgroup with low heterogeneity to confirm the impact of heterogeneity between SGLT2i groups in our meta-analysis. Incidentally, in our analysis, all SGLT2i groups with different doses in the treatment arm were combined into a single group based on the Cochrane Handbook [13]. In contrast, the study by Cai and colleagues [11] included only the standard dose of SGLT2is in each treatment arm; however, the impact of this methodological difference across meta-analyses currently remains unclear.

An increase of $1 \mathrm{mg} / \mathrm{dL}$ in HDL-C from baseline after 3 months may be expected to reduce the risk of major cardiovascular events by $1.1 \%$ in the post-hoc analysis of 


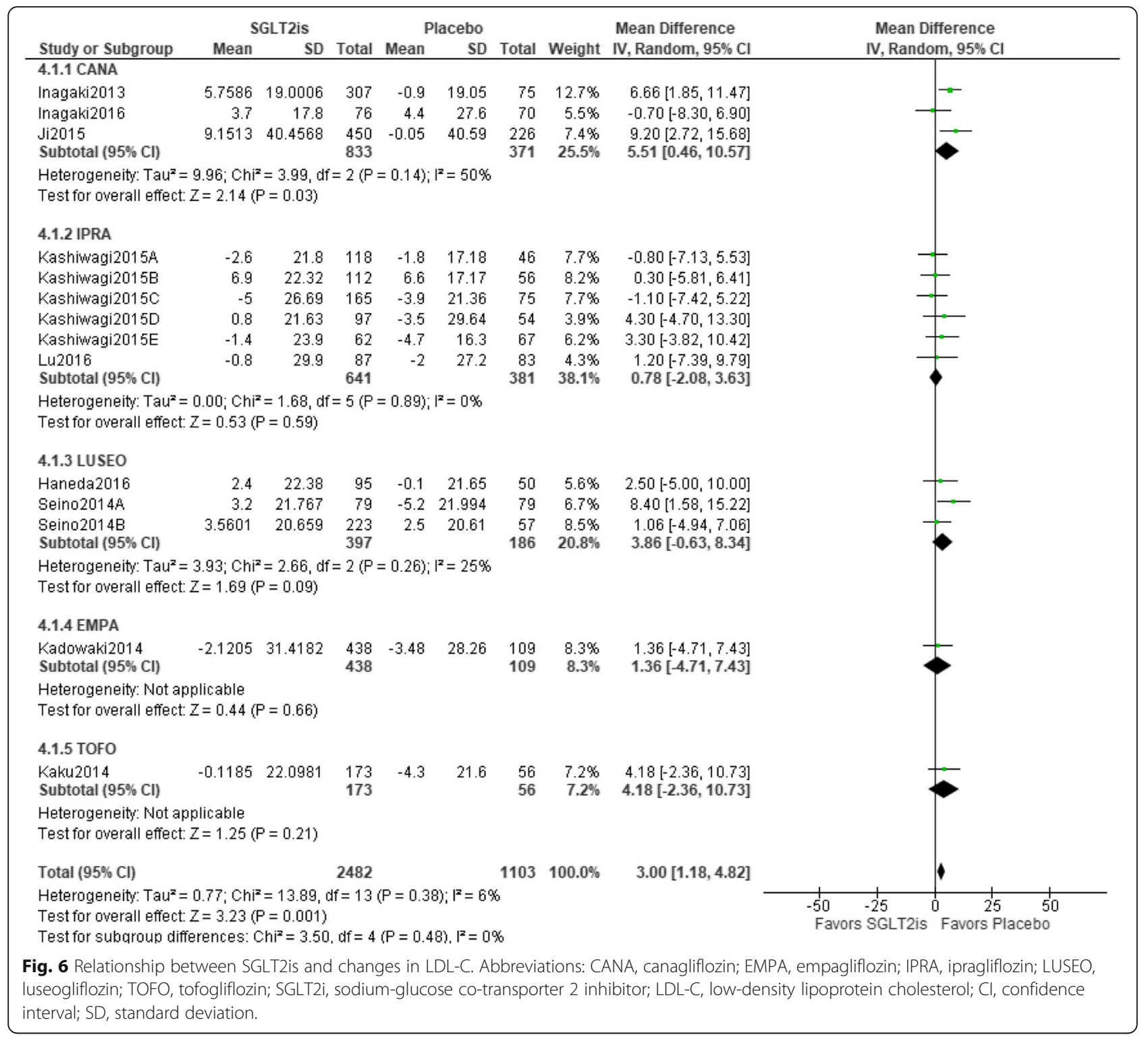

the TNT trial [34]. Similarly, all RCTs included showed consistent increases in HDL-C of $1 \mathrm{mg} / \mathrm{dL}$ or more from baseline after approximately 3 months before these RCTs were combined. HDL-C was $3.4 \mathrm{mg} / \mathrm{dL}$ higher with SGLT2is than with a placebo in our meta-analysis. This result suggests that SGLT2is exert protective effects against cardiovascular events in Asian populations. The present meta-analysis showed that SGLT2is decreased TG by $16.4 \mathrm{mg} / \mathrm{dL}$ and increased LDL-C by $3.0 \mathrm{mg} / \mathrm{dL}$ from placebo values. A recent meta-regression analysis with an average median trial duration of 4.8 years showed that the risk ratio of major vascular events was 0.92 per $40 \mathrm{mg} / \mathrm{dL}$ reduction in TG [35]. Another metaanalysis with a mean follow-up of 4.3 years [36] reported a $21 \%$ reduction in major vascular events per $1 \mathrm{mmol} / \mathrm{L}$ $(38.7 \mathrm{mg} / \mathrm{dL})$ reduction in LDL-C. Further RCTs with a longer duration are needed to establish whether the modest changes observed in TG and LDL-C in our meta-analysis are of clinical importance because the maximum duration of RCT in our review was too short (at most 24 weeks).

The RCT that included approximately $80 \%$ Caucasians also demonstrated that CANA at $300 \mathrm{mg}$ increased TG by $20.2 \mathrm{mg} / \mathrm{dL}$ over the placebo value [37], while the results for TG in our meta-analysis showed the opposite effect [mean difference-16.42 (95\%CI -22.71 to 10.12) $\mathrm{mg} / \mathrm{dL}$ ]. The EMPA-REG OUTCOME study [2, 38 ], which included $72 \%$ Caucasians, and the RCT by Bode and colleagues [39], comprising $70 \%$ or more Caucasians, showed small increases in HDL-C and LDL-C over those with the placebo. The magnitude of effects on HDL-C and LDL-C were equal to the results of the 


\begin{tabular}{|c|c|c|c|c|c|c|c|c|c|}
\hline \multirow[b]{2}{*}{ Study or Subgroup } & \multicolumn{3}{|c|}{ SGLT2is } & \multicolumn{2}{|c|}{ Placebo } & \multirow[b]{2}{*}{ Total } & \multirow[b]{2}{*}{ Weight } & \multirow{2}{*}{$\begin{array}{l}\text { Mean Difference } \\
\text { IV, Random, } 95 \% \mathrm{Cl}\end{array}$} & \multirow{2}{*}{$\begin{array}{c}\text { Mean Difference } \\
\text { IV, Random, } 95 \% \mathrm{Cl}\end{array}$} \\
\hline & Mean & SD & Total & Mean & SD & & & & \\
\hline \multicolumn{10}{|l|}{ 5.1.1 CANA } \\
\hline Inagaki2013 & -0.0481 & 0.3525 & 307 & -0.007 & 0.3525 & 75 & $58.7 \%$ & $-0.04[-0.13,0.05]$ & 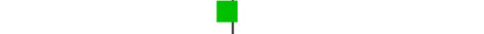 \\
\hline Ji2015 & -0.0102 & 0.8993 & 450 & -0.09 & 0.902 & 226 & $22.7 \%$ & $0.08[-0.06,0.22]$ & - \\
\hline Subtotal $(95 \% \mathrm{Cl})$ & & & 757 & & & 301 & $81.5 \%$ & $0.01[-0.11,0.12]$ & \\
\hline \multicolumn{10}{|c|}{$\begin{array}{l}\text { Heterogeneity: } \text { Tau }^{2}=0.00 ; C h i^{2}=1.96, d f=1(P=0.16) ; l^{2}=49 \% \\
\text { Test for overall effect: } Z=0.09(P=0.92)\end{array}$} \\
\hline \multicolumn{10}{|l|}{ 5.1.3 LUSEO } \\
\hline $\begin{array}{l}\text { Haneda2016 } \\
\text { Subtotal }(95 \% \mathrm{Cl})\end{array}$ & -0.133 & 0.4227 & $\begin{array}{l}95 \\
95\end{array}$ & -0.103 & 0.487 & $\begin{array}{l}50 \\
50\end{array}$ & $\begin{array}{l}18.5 \% \\
18.5 \%\end{array}$ & $\begin{array}{c}-0.03[-0.19,0.13] \\
-0.03[-0.19,0.13]\end{array}$ & $=$ \\
\hline \multicolumn{10}{|c|}{$\begin{array}{l}\text { Heterogeneity: Not applicable } \\
\text { Test for overall effect: } Z=0.37(P=0.71)\end{array}$} \\
\hline Total $(95 \% \mathrm{Cl})$ & & & 852 & & & 351 & $100.0 \%$ & $-0.01[-0.08,0.06]$ & 4 \\
\hline \multicolumn{9}{|c|}{$\begin{array}{l}\text { Heterogeneity: } \text { Tau }^{2}=0.00 ; \mathrm{Chi}^{2}=2.02, \mathrm{df}=2(\mathrm{P}=0.36) ; \mathrm{I}^{2}=1 \% \\
\text { Test for overall effect: } Z=0.33(\mathrm{P}=0.74) \\
\text { Test for subqroup differences: } \mathrm{Chi}^{2}=0.13, \mathrm{df}=1(\mathrm{P}=0.72), \mathrm{I}^{\mathrm{z}}=0 \%\end{array}$} & $\begin{array}{ccccc}1 & 1 & 1 & 1 & 1 \\
-2 & -1 & 0 & 1 & 2 \\
& \text { Favors SGLT2is } & & \\
& \text { Favors Placebo }\end{array}$ \\
\hline \multicolumn{10}{|c|}{$\begin{array}{l}\text { Fig. } 7 \text { Relationship between SGLT2is and changes in the LDL-C/HDL-C ratio. Abbreviations: CANA, canagliflozin; LUSEO, luseogliflozin; SGLT2i, } \\
\text { sodium-glucose co-transporter } 2 \text { inhibitor; HDL-C, high-density lipoprotein cholesterol; LDL-C, low-density lipoprotein cholesterol; Cl, confidence } \\
\text { interval; SD, standard deviation. }\end{array}$} \\
\hline
\end{tabular}

present study including 100\% Asian patients [mean difference 3.36 (95\%CI 2.73 to 3.98$) \mathrm{mg} / \mathrm{dL}$, mean difference 3.00 (95\%CI 1.18 to 4.82$) \mathrm{mg} / \mathrm{dL}$, respectively]. Therefore, the effects of SGLT2is on HDL-C and LDL-C do not appear to be dependent on race, although racial differences may explain this smaller increase in TG; however, differences in the types of SGLT2is used, such as CANA and EMPA, or patient backgrounds, which included those treated with antihyperlipidemic therapies or statins, may have affected this result $[2,37-39]$. Further studies are needed to verify whether racial differences affect lipid metabolism.
Regardless of the types of SGLT2is, consistent results, such as a decrease in TG and increases in HDL-C and LDL-C, were observed in our meta-analysis. Similarly, weight loss in patients with type 2 diabetes mellitus in UKPDS reduced TG with an increase in HDL-C [40]. Weight loss with SGLT2is may explain, in part, the better TG and HDL-C values observed. Overall, there was no significant change in the LDL-C/HDL-C ratio in our analysis. This result supports the hypothesis that the increase in LDL-C induced by SGLT2is may be counterbalanced by elevated HDL-C [41]. A possible mechanism for the increase observed in LDL-C with SGLT2is is explained using a preclinical model. This increase may be

Table 2 Summary of subgroup analyses

\begin{tabular}{|c|c|c|c|c|c|c|c|}
\hline & Outcome & $\begin{array}{l}\text { Trial, } \\
\mathrm{n}\end{array}$ & $\begin{array}{l}\text { SGLT2i, } \\
\mathrm{n}\end{array}$ & $\begin{array}{l}\text { Placebo, } \\
\text { n }\end{array}$ & $\begin{array}{l}\text { Mean difference } \\
{[95 \% \mathrm{Cl}]}\end{array}$ & $\begin{array}{l}\text { Heterogeneity } \\
\text { (\%) }\end{array}$ & $\begin{array}{l}\text { Test for the overal } \\
\text { effect } \\
\text { ( } p \text { value) }\end{array}$ \\
\hline \multirow[t]{5}{*}{ Only Japanese patients } & $\mathrm{HbA1c}(\%)$ & 13 & 1998 & 866 & $\begin{array}{l}-0.83[-1.01,- \\
0.65]\end{array}$ & 90 & $<0.00001$ \\
\hline & $\mathrm{TG}(\mathrm{mg} / \mathrm{dL})$ & 13 & 2127 & 848 & $\begin{array}{l}-14.39[-20.80 \\
-7.98]\end{array}$ & 0 & $<0.0001$ \\
\hline & $\mathrm{HDL}-\mathrm{C}(\mathrm{mg} / \mathrm{dL})$ & 12 & 1945 & 794 & $3.58[2.90,4.25]$ & 0 & $<0.00001$ \\
\hline & $\mathrm{LDL}-\mathrm{C}(\mathrm{mg} / \mathrm{dL})$ & 12 & 1945 & 794 & $2.59[0.72,4.46]$ & 0 & 0.007 \\
\hline & $\begin{array}{l}\mathrm{LDL}-\mathrm{C} / \mathrm{HDL}-\mathrm{C} \\
\text { ratio }\end{array}$ & 2 & 402 & 125 & $-0.04[-0.12,0.04]$ & 0 & 0.33 \\
\hline \multirow{5}{*}{$\begin{array}{l}\text { Only patients treated with SGLT2i as } \\
\text { monotherapy }\end{array}$} & $\mathrm{HbA1c}(\%)$ & 8 & 1596 & 647 & $-0.84[-0.97,-0.70]$ & 77 & $<0.00001$ \\
\hline & $\mathrm{TG}(\mathrm{mg} / \mathrm{dL})$ & 7 & 1464 & 497 & $\begin{array}{l}-17.96[-27.03 \\
-8.88]\end{array}$ & 0 & 0.0001 \\
\hline & $\mathrm{HDL}-\mathrm{C}(\mathrm{mg} / \mathrm{dL})$ & 6 & 1282 & 443 & $3.89[3.01,4.76]$ & 0 & $<0.00001$ \\
\hline & $\mathrm{LDL}-\mathrm{C}(\mathrm{mg} / \mathrm{dL})$ & 6 & 1282 & 443 & $4.29[1.81,6.76]$ & 0 & 0.0007 \\
\hline & $\begin{array}{l}\mathrm{LDL}-\mathrm{C} / \mathrm{HDL}-\mathrm{C} \\
\text { ratio }\end{array}$ & 1 & 307 & 75 & $-0.04[-0.13,0.05]$ & NA & 0.37 \\
\hline
\end{tabular}


due to the delayed clearance of LDL from the circulation along with elevated plasma lipoprotein lipase activity [42].

The present study has some limitations. Although Egger's regression test showed no significant differences in primary outcomes, there may have been a publication bias because we only retrieved published studies. Furthermore, our review was unable to rule out the impact of other antihyperglycemic agents because it included some patients who were treated with an oral hypoglycemic agent or insulin as combination therapy. However, the results of the subgroup analysis that only included patients who were treated with SGLT2is as monotherapy were consistent with the main results (Table 2). Similarly, some lifestyle interventions, such as diet and exercise, which had been performed in most of the RCTs collected, may also have contributed to our lipid outcomes because these interventions are known to affect lipid profiles $[43,44]$. The combination of lifestyle intervention(s) and oral hypoglycemic agent therapy is commonly used in clinical practice. In addition, the results obtained are hard to generalize for other Asian populations. The results of the sub-group analysis that included Japanese patients only were consistent with the main results. A possible reason for this is that Japanese patients accounted for $80 \%$ of the Asian population in this review. Another limitation is that the numbers of different types of SGLT2is that we pooled were unbalanced. There were also no lipid outcomes including all types of SGLT2is in our meta-analysis. The IRPA group with the highest weight may have affected all lipid profiles.

\section{Conclusion}

In summary, the present results suggest that in Asian patients with type 2 diabetes, TG and HDL-C values were better, while LDL-C values were worse with SGLT2is than with a placebo. However, the negative impact of SGLT2is on lipid profiles was modest. Further RCT with a longer duration or conducted in other Asia countries are needed to provide further evidence to support the clinical relevance of changes in lipid profiles. The present results will be informative for SGLT2is users with concerns regarding the effects of SGLT2is on lipid profiles.

\section{Abbreviations}

CANA: Canagliflozin; Cl: Confidence interval; DAPA: Dapagliflozin; EMPA: Empagliflozin; HDL-C: High-density lipoprotein cholesterol; IPRA: Ipragliflozin; LDL-C: Low-density lipoprotein cholesterol; LUSEO: Luseogliflozin; RCT: Randomized controlled trial; SGLT2i: Sodiumglucose co-transporter 2 inhibitor; TG: Triglycerides; TOFO: Tofogliflozin

\section{Acknowledgments}

Not applicable.

\section{Authors' contributions}

JM conceived and designed the study. JM and AY performed the systematic review of the literature. JM and AY analyzed and interpreted the data. JM wrote the manuscript. All authors read and approved the final manuscript.

\section{Availability of data and materials}

The datasets used and/or analyzed during the present study are available from the corresponding author on reasonable request.

Ethics approval and consent to participate

Not applicable.

\section{Consent for publication}

Not applicable.

\section{Competing interests}

The authors declare that they have no competing interests.

Received: 23 January 2020 Accepted: 3 March 2020

Published online: 14 March 2020

\section{References}

1. Monami M, Nardini C, Mannucci E. Efficacy and safety of sodium glucose co-transport-2 inhibitors in type 2 diabetes: a meta-analysis of randomized clinical trials. Diabetes Obes Metab. 2014:16:457-66.

2. Zinman B, Wanner C, Lachin JM, Fitchett D, Bluhmki E, Hantel S, Mattheus M, Devins T, Johansen OE, Woerle HJ, Broedl UC. Inzucchi SE; EMPA-REG OUTCOME investigators. Empagliflozin, cardiovascular outcomes, and mortality in type 2 diabetes. N Engl J Med. 2015:373:2117-28.

3. Neal B, Perkovic V, Mahaffey KW, de Zeeuw D, Fulcher G, Erondu N, Shaw W, Law G, Desai M, Matthews DR, CANVAS Program Collaborative Group. Canagliflozin and cardiovascular and renal events in type 2 diabetes. N Engl Jed. 2017:377:644-57

4. Okamura T, Kokubo Y, Watanabe M, Higashiyama A, Miyamoto Y, Yoshimasa Y, Okayama A. Low-density lipoprotein cholesterol and non-high-density lipoprotein cholesterol and the incidence of cardiovascular disease in an urban Japanese cohort study: the Suita study. Atherosclerosis. 2009;203:587-92.

5. Pekkanen J, Linn S, Heiss G, Suchindran CM, Leon A, Rifkind BM, Tyroler HA. Ten-year mortality from cardiovascular disease in relation to cholesterol level among men with and without preexisting cardiovascular disease. $\mathrm{N}$ Engl J Med. 1990;322:1700-7.

6. American Diabetes Association. 9. Pharmacologic approaches to glycemic treatment: standards of medical care in diabetes-2019. Diabetes Care. 2019; 42:S90-102.

7. Kaku K, Kiyosue A, Inoue S, Ueda N, Tokudome T, Yang J, Langkilde AM. Efficacy and safety of dapagliflozin monotherapy in Japanese patients with type 2 diabetes inadequately controlled by diet and exercise. Diabetes Obes Metab. 2014;16:1102-10.

8. Yoon $\mathrm{KH}$, Lee JH, Kim JW, Cho JH, Choi YH, Ko SH, Zimmet P, Son HY. Epidemic obesity and type 2 diabetes in Asia. Lancet. 2006;368:1681-8.

9. WHO Expert Consultation. Appropriate body-mass index for Asian populations and its implications for policy and intervention strategies. Lancet. 2004:363:157-63.

10. Zhang C, Gao F, Luo H, Zhang CT, Zhang R. Differential response in levels of high-density lipoprotein cholesterol to one-year metformin treatment in prediabetic patients by race/ethnicity. Cardiovasc Diabetol. 2015;14:79.

11. Cai X, Gao X, Yang W, Chen Y, Zhang S, Zhou L, Han X, Ji L. No disparity of the efficacy and all-cause mortality between Asian and non-Asian type 2 diabetes patients with sodium-glucose cotransporter 2 inhibitors treatment: a meta-analysis. J Diab Investig. 2018;9:850-61.

12. Jadad AR, Moore RA, Carroll D, Jenkinson C, Reynolds DJ, Gavaghan DJ, McQuay HJ. Assessing the quality of reports of randomized clinical trials: is blinding necessary? Control Clin Trials. 1996;17:1-12.

13. Higgins JPT, Green S (eds). Cochrane handbook for systematic reviews of interventions, Version 5.1.0 [updated March 2011]: The Cochrane Collaboration; 2011. http://handbook.cochrane.org/. Accessed 16 July 2019.

14. DerSimonian R, Laird N. Meta-analysis in clinical trials. Control Clin Trials. 1986:7:177-88.

15. Egger M, Davey Smith G, Schneider M, Minder C. Bias in meta-analysis detected by a simple, graphical test. BMJ. 1997;315:629-34.

16. Ji L, Ma J, Li H, Mansfield TA, T'joen CL, labal N, Ptaszynska A, List JF. Dapagliflozin as monotherapy in drug-naive Asian patients with type 2 diabetes mellitus: a randomized, blinded, prospective phase III study. Clin Ther. 2014;36:84-100 e9.

17. Kadowaki T, Haneda M, Inagaki N, Terauchi $Y$, Taniguchi A, Koiwai $K$ Rattunde H, Woerle HJ, Broedl UC. Empagliflozin monotherapy in Japanese 
patients with type 2 diabetes mellitus: a randomized, 12-week, doubleblind, placebo-controlled, phase II trial. Adv Ther. 2014;31:621-38.

18. Kashiwagi A, Takahashi H, Ishikawa H, Yoshida S, Kazuta K, Utsuno A, Ueyama E. A randomized, double-blind, placebo-controlled study on longterm efficacy and safety of ipragliflozin treatment in patients with type 2 diabetes mellitus and renal impairment: results of the long-term ASP1941 safety evaluation in patients with type 2 diabetes with renal impairment (LANTERN) study. Diabetes Obes Metab. 2015;17:152-60.

19. Lu CH, Min KW, Chuang LM, Kokubo S, Yoshida S, Cha BS. Efficacy, safety, and tolerability of ipragliflozin in Asian patients with type 2 diabetes mellitus and inadequate glycemic control with metformin: results of a phase 3 randomized, placebo-controlled, double-blind, multicenter trial. J Diab Investig. 2016;7:366-73.

20. Kashiwagi A, Kazuta K, Goto K, Yoshida S, Ueyama E, Utsuno A. Ipragliflozin in combination with metformin for the treatment of Japanese patients with type 2 diabetes: ILLUMINATE, a randomized, double-blind, placebocontrolled study. Diabetes Obes Metab. 2015;17:304-8.

21. Kashiwagi A, Akiyama N, Shiga T, Kazuta K, Utsuno A, Yoshida S, Ueyama E. Efficacy and safety of Ipragliflozin as an add-on to a sulfonylurea in Japanese patients with inadequately controlled type 2 diabetes: results of the randomized, placebo-controlled, double-blind, phase III EMIT study. Diabetol Int. 2015;6:125-38

22. Kashiwagi A, Shiga T, Akiyama N, Akiyama N, Kazuta K, Utsuno A Yoshida S, Ueyama E. Efficacy and safety of Ipragliflozin as an addon to pioglitazone in Japanese patients with inadequately controlled type 2 diabetes: a randomized, double-blind, placebocontrolled study (the SPOTLIGHT study). Diabetol Int. 2015;6:104-16.

23. Kashiwagi A, Kazuta K, Takinami Y, Yoshida S, Utsuno A, Nagase I. Ipragliflozin improves glycemic control in Japanese patients with type 2 diabetes mellitus: the BRIGHTEN study. Diabetol Int. 2015;6:8-18.

24. Haneda M, Seino Y, Inagaki N, Kaku K, Sasaki T, Fukatsu A, Kakiuchi H, Sato Y, Sakai S, Samukawa Y. Influence of renal function on the 52-week efficacy and safety of the sodium glucose cotransporter 2 inhibitor luseogliflozin in Japanese patients with type 2 diabetes mellitus. Clin Ther. 2016;38:66-88 e20.

25. Seino Y, Sasaki T, Fukatsu A, Ubukata M, Sakai S, Samukawa Y. Efficacy and safety of luseogliflozin as monotherapy in Japanese patients with type 2 diabetes mellitus: a randomized, double-blind, placebo-controlled, phase 3 study. Curr Med Res Opin. 2014;30:1245-55.

26. Seino Y, Sasaki T, Fukatsu A, Ubukata M, Sakai S, Samukawa Y. Dose-finding study of luseogliflozin in Japanese patients with type 2 diabetes mellitus: a 12-week, randomized, double-blind, placebo-controlled, phase II study. Curr Med Res Opin. 2014;30:1231-44.

27. Seino Y, Sasaki T, Fukatsu A, Sakai S, Samukawa Y. Efficacy and safety of luseogliflozin monotherapy in Japanese patients with type 2 diabetes mellitus: a 12-week, randomized, placebo-controlled, phase II study. Curr Med Res Opin. 2014;30:1219-30.

28. Inagaki N, Harashima S, Maruyama N, Kawaguchi Y, Goda M, lijima H. Efficacy and safety of canagliflozin in combination with insulin: a doubleblind, randomized, placebo-controlled study in Japanese patients with type 2 diabetes mellitus. Cardiovasc Diabetol. 2016;15:89.

29. Ji L, Han P, Liu Y, Yang G, Dieu Van NK, Vijapurkar U, Qiu R, Meininger G. Canagliflozin in Asian patients with type 2 diabetes on metformin alone or metformin in combination with sulphonylurea. Diabetes Obes Metab. 2015;17:23-31.

30. Inagaki N, Kondo K, Yoshinari T, Takahashi N, Susuta Y, Kuki H. Efficacy and safety of canagliflozin monotherapy in Japanese patients with type 2 diabetes inadequately controlled with diet and exercise: a 24-week, randomized, double-blind, placebo-controlled, Phase III study. Expert Opin Pharmacother. 2014;15:1501-15.

31. Inagaki N, Kondo K, Yoshinari T, Maruyama N, Susuta Y, Kuki H. Efficacy and safety of canagliflozin in Japanese patients with type 2 diabetes: a randomized, double-blind, placebo-controlled, 12-week study. Diabetes Obes Metab. 2013;15:1136-45.

32. Kaku K, Watada H, Iwamoto Y, Utsunomiya K, Terauchi Y, Tobe K, Tanizawa Y, Araki E, Ueda M, Suganami H, Watanabe D. Tofogliflozin 003 Study Group. Efficacy and safety of monotherapy with the novel sodium/glucose cotransporter-2 inhibitor tofogliflozin in Japanese patients with type 2 diabetes mellitus: a combined Phase 2 and 3 randomized, placebocontrolled, double-blind, parallel-group comparative study. Cardiovasc Diabetol. 2014;13:65.

33. Moher D, Liberati A, Tetzlaff J, Altman DG, PRISMA Group. Preferred reporting items for systematic reviews and meta-analyses: the PRISMA statement. Ann Intern Med. 2009;151:264-9.
34. Barter P, Gotto AM, LaRosa JC, Maroni J, Szarek M, Grundy SM, Kastelein JJ, Bittner $\mathrm{V}$, Fruchart JC. Treating to new targets investigators. HDL cholesterol, very low levels of LDL cholesterol, and cardiovascular events. N Engl J Med. 2007:357:1301-10.

35. Marston NA, Giugliano RP, Im K, Silverman MG, O'Donoghue ML, Wiviott SD, Ference BA, Sabatine MS. Association between triglyceride lowering and reduction of cardiovascular risk across multiple lipid-lowering therapeutic classes: a systematic review and meta-regression analysis of randomized controlled trials. Circulation. 2019;140:1308-17.

36. Cholesterol Treatment Trialists' (CTT) Collaborators, Kearney PM, Blackwell L, Collins R, Keech A, Simes J, Peto R, Armitage J, Baigent C. Efficacy of cholesterol-lowering therapy in 18,686 people with diabetes in 14 randomised trials of statins: a meta-analysis. Lancet. 2008;371:117-25.

37. Yale JF, Bakris G, Cariou B, Yue D, David-Neto E, Xi L, Figueroa K, Wajs E, Usiskin K, Meininger G. Efficacy and safety of canagliflozin in subjects with type 2 diabetes and chronic kidney disease. Diabetes Obes Metab. 2013;15:463-73.

38. Zinman B, Inzucchi SE, Lachin JM, Wanner C, Ferrari R, Fitchett D, Bluhmki E, Hantel S, Kempthorne-Rawson J, Newman J, Johansen OE, Woerle HJ, Broedl UC. Rationale, design, and baseline characteristics of a randomized, placebo-controlled cardiovascular outcome trial of empagliflozin (EMPA-REG OUTCOME ${ }^{\mathrm{TM}}$ ). Cardiovasc Diabetol. 2014;13:102.

39. Bode B, Stenlöf K, Harris S, Sullivan D, Fung A, Usiskin K, Meininger G. Longterm efficacy and safety of canagliflozin over 104 weeks in patients aged 55-80 years with type 2 diabetes. Diabetes Obes Metab. 2015;17:294-303.

40. Manley SE, Stratton IM, Cull CA, Frighi V, Eeley EA, Matthews DR, Holman RR, Turner RC, Neil HA, United Kingdom Prospective Diabets Study Group. Effects of three months' diet after diagnosis of Type 2 diabetes on plasma lipids and lipoproteins (UKPDS 45). Diabet Med. 2000;17:518-23.

41. Halimi S, Vergès B. Adverse effects and safety of SGLT-2 inhibitors. Diabetes Metab. 2014:40:528-34.

42. Basu D, Huggins LA, Scerbo D, Obunike J, Mullick AE, Rothenberg PL, Di Prospero NA, Eckel RH, Goldberg IJ. Mechanism of increased LDL (low-density lipoprotein) and decreased triglycerides with SGLT2 (sodium-glucose Cotransporter 2) inhibition. Arterioscler Thromb Vasc Biol. 2018;38:2207-16.

43. Heilbronn LK, Noakes M, Clifton PM. Effect of energy restriction, weight loss, and diet composition on plasma lipids and glucose in patients with type 2 diabetes. Diabetes Care. 1999;22:889-95.

44. Kelley GA, Kelley KS. Effects of aerobic exercise on lipids and lipoproteins in adults with type 2 diabetes: a meta-analysis of randomized-controlled trials. Public Health. 2007;121:643-55.

\section{Publisher's Note}

Springer Nature remains neutral with regard to jurisdictional claims in published maps and institutional affiliations.

Ready to submit your research? Choose BMC and benefit from:

- fast, convenient online submission

- thorough peer review by experienced researchers in your field

- rapid publication on acceptance

- support for research data, including large and complex data types

- gold Open Access which fosters wider collaboration and increased citations

- maximum visibility for your research: over $100 \mathrm{M}$ website views per year

At $\mathrm{BMC}$, research is always in progress.

Learn more biomedcentral.com/submissions 